\title{
Knowledge, Faith, Morality, and the Future of Humanity
}

The International Symposium on Bediuzzaman Said Nursi, held in Istanbul from 3-5 October 2010 under the auspices of Istanbul Ilim ve Kültür Vakfi (www.sempozyum2010.com and www.barlaplatformu.com), coincided with the fiftieth anniversary of this great Muslim social reformer's death. Its theme, "Knowledge, Faith, Morality, and the Future of Humanity," attracted academics, scholars, and writers from around the world who sought to explore and examine The Risale-i Nur's contributions to human peace, prosperity, and happiness. The 106 peer-reviewed papers presented were divided into three separate volumes according to language: Turkish (13 papers), Arabic (50 papers), and English (43 papers and the keynote address).

Farid Al-Attas's (professor of sociology, National University of Singapore; head, Department of Malay Studies) keynote address: "The Social Theology of Bediuzzaman Said Nursi and the Critique of Modern Civilization," proposed that one has to consider Nursi's engagement with society through his understanding and application of theology. This social theology, he argued, has to be juxtaposed with the ideas of western and Asian scholars in order to fully appreciate Said Nursi's ideas when compared with those Max Weber (Europe), Jose Rizal (Southeast Asia), and others. This particular session was chaired by Ibrahim Abu Rabi' (University of Alberta, Canada), editor of Islam at the Crossroads: On the Life and Thought of Bediuzzaman Said Nursi (Albany: State University of New York Press, 2003), 
Islam in Modern Turkey: An Intellectual Biography of Bediuzzaman Said Nursi (Albany: State University of New York Press, 2005), Theodicy and Justice in Modern Islamic Thought: The Case of Said Nursi (London: Ashgate, 2010), and author of Spiritual Dimensions of Bediuzzaman Said Nursiś Risale-i-Nur (Albany: State University of New York Press, 2008).

AfterAl-Attas' significant keynote input, the general parallel sessions got underway. Of the four sessions presented on 4 and 5 October, the last sessions of which were devoted to special post-graduate studies panels moderated by David Goa (University of Alberta). They were set up to focus upon "religion and culture" and "globalization and the Risale i-Nur," respectively, in order to get a sense of how young emerging scholars understand and reflect upon these themes. These interesting panels showcased how eight young scholars engaged with Nursi's ideas and related them to the mentioned themes. The organizers divided the two days of proceedings into four parallel sessions per day consisting of twelve sessions each day. According to the program booklet there were ninety-four presentations - an average of four per session. The categories of papers presented ranged from "Nursi's Understanding of Mutual Assistance, Compassion, and Solidarity" to "Solutions for Problems Stemming from Religious Differences." A general overview of particular sessions and specific papers follows.

One of the first parallel sessions, "Faith and Knowledge," was chaired by Thomas Michel (Georgetown University, USA), who had earlier brought some of his writings together in his monograph entitled Said Nursiš Views on Muslim-Christian Understanding (Istanbul: 2005). This session featured Najib Ali Abdallah al-Sudi (Taiz University, Yemen), who addressed "The Relation between Knowledge and Faith as Nursi Sees It," Bilal Kuspinar (Ahlia University, Bahrain), who discussed "The Fusion of Faith and Knowledge in Finding Solutions for Problems: Nursi's Illuminative Path," and Sener Dilek (Inonu University, Turkey), who reflected on "Said Nursi's Progress of Knowledge: Mana-yi Harfi (the Indicative Meaning), Mana-yi Ismî (the Meaning of Things) Referring Themselves to Niyet (Intention) and Nazar (Vision). Kuapinar's paper demonstrated to what extent Said Nursi successfully integrated the religious sciences with the modern sciences and for having advocated reforms in the Muslim educational system so that their integration could be realized.

One of the first day's final parallel sessions, chaired by Ammar Djidal (Algeria University), focused mainly on Christian-Muslim relations as observed in Nursi's writings. Wilhelmus Valkenberg (Loyola University, USA) opened with "Said Nursi's Commentary on Surat Al-Fatiha: Its Role in Dialogue and Mutual Understanding between Christians and Muslims." 
Awad Abbas Abdulameer Al Hardan (Ahlia University, Iraq) analyzed "The Dialogue among Religions: Analytical Reading according to Said Nursi's Perspectives," Cristoph Elsas (Marburg University, Germany) discussed "Muslim and Christian Service Based on Human Impotence and Bareness: Nursi's and Eckhart's Solutions for Problems," and Adnan Mustafa Khatatbeh (Yarmuk University, Jordan) tackled the "Influence of Faith in Awakening the Quality of Mercy within the Human Self." While Valkenberg's title provided a fairly clear idea of what he examined in his paper, this was not so after having glanced at the title of Elsas' paper. Despite this, Elsas' interesting paper assessed and compared the notion of "calmness" in the respective texts of Said Nursi (d. 1960) and Meister Eckhart (d. 1260) as a useful tool to resolve problems encountered by communities.

Several individual papers were quite informative and complemented the variety of the other papers. Even though these papers varied in quality and length, they helped shed light on how Nursi's thoughts have been understood and dissected by scholars from diverse disciplines and many countries. This is tangible proof that his ideas have spread far and wide and that his thoughts remain relevant fifty years after his death. In many papers, his ideas were compared with those of Meister Eckhart, Jamal ad-Din al-Afghani, Sayyid Qutb, and Pope John Paul II. Other scholars concentrated on specific concepts and ideas (e.g., faith, ethics, and science) that Nursi stressed throughout his writings.

Hasan Horkuc (Durham University, UK) critically examined "Said Nursi (Who) Reactivated Pro-Active Islamic Ethics and Injunctions," Andi Faisal Bakti (Syarif Hidayatullah Islamic University, Indonesia) investigated "The Contribution of Da wah to Communication Studies: Risale- $i$ Nur Collection Perspective," Michael J. Lenaghan (Miami Dade College, USA) located "Bediuzzaman Said Nursi in a Pluralistic World: (by discussing the) Channel of Truth, Peace, Sustainable Change," and Norshahril Bin Saat (Singapore National University) looked at "Said Nursi and the Concept of Progress." Stephen W. Need (Jerusalem St. George University, Israel) scrutinized "Justice and Non-Violence in Israel and Palestine: The Contribution of Bediuzzaman Said Nursi," Ibnor Azli (National University of Malaysia) unpacked the concept of "Iman as a Focal Point and Beacon of Light in Risale-i Nur," and Vaffi F. Sheriff (Usmano Danfodio University, Nigeria) addressed "The Role of Faith in Developing a Sense of Responsibility and Accountability." Sayed Abdul Muneem Pasha (National Islamic University, India) reflected upon "Said Nursi's Thought: Its Relevance for the Twenty-First Century." 
The variety of topics discussed and addressed seem to underscore that Bediuzzaman Said Nursi's role as a social reformer in Turkey has significance for both Muslim and non-Muslim communities far beyond the borders of Turkey. All papers contained in the symposium's three volumes demonstrate that not only is he a historical figure, but he is also an inspirational and transformational figure whose work will remain relevant for the foreseeable future.

Muhammed Haron Associate Professor of Religious Studies University of Botswana, Garbarone 